\title{
Total Quality Management (TQM) Adoption in Bangladesh Ready-Made Garments (RMG) Industry: A Conceptual Model
}

\author{
Farhana Rashid, Che Azlan Taibb \\ School of Technology Management and Logistics (STML), College of Business (COB), Universiti Utara Malaysia, Kedah, Malaysia \\ Email: rashid.farhana@gmail.com
}

How to cite this paper: Rashid, F. and Taibb, C.A. (2016) Total Quality Management (TQM) Adoption in Bangladesh ReadyMade Garments (RMG) Industry: A Conceptual Model. American Journal of Industrial and Business Management, 6, 10851101 .

http://dx.doi.org/10.4236/ajibm.2016.611102

Received: October 13, 2016

Accepted: November 21, 2016

Published: November 24, 2016

Copyright (c) 2016 by authors and Scientific Research Publishing Inc. This work is licensed under the Creative Commons Attribution International License (CC BY 4.0).

http://creativecommons.org/licenses/by/4.0/

\begin{abstract}
Bangladesh Ready-Made Garments (RMG) sector shows remarkable growth and significant contribution in the country's economic development though product and service qualities are yet a considerable problem to worry about. RMG companies in Bangladesh are not fully aware about the impacts and value of Total Quality Management (TQM) implementation. Actually they mostly give emphasis on ISO 9000 execution and various researches show that application of this only enhances problems. Researchers argue that effective implementation of TQM practices is a main criteria and predictor of gaining sustainability in business. So, for being competitive in the long run, RMG industry in Bangladesh should focus more on TQM practices rather than taking advantages out of the cheapest labors. As, it is notable to mention that in case of Bangladesh RMG sector, most of the existing literatures give more emphasis and discuss about the infrastructural and strategic matters whereas TQM and Human Resource Management (HRM) practices in an attempt to improve sustainable competitive advantage are still a debate both theoretically as well as empirically. In this aspect, literatures proved that, no previous studies were conducted to verify the association among practices of TQM, sustainable competitive advantage as well as the role of HRM as a mediator to build TQM climate in Bangladesh RMG sector. In order to bridge this gap and to generate a more comprehensive argument, this paper further proposes and aims at providing a tool, a procedural framework, to enhance TQM in various RMG companies operating in Bangladesh via the development of appropriate TQM model which will ensure organizational sustainable competitive advantage where HRM practices will consider as mediating variable. Proposed research direction and conclusion are discussed in conclusion of this research.
\end{abstract}

\section{Keywords}

Total Quality Management, Sustainable Competitive Advantage, Human Resource 
Management practices, RMG

\section{Introduction}

Bangladesh garments manufacturing industry is expanding at a rate of $20 \%$ per year [1] [2] and around 76\% of the export earnings come from RMG sector [3]. Currently 4.2 million workers are working in this sector where 4490 manufacturing units are in operation [4]. At the same time, Bangladesh garments industry fully labor intensive rather than technology oriented as Bangladesh is the cheapest labor country where the average labor cost per hour is only $\$ 0.3$ [5]. RMG sector contributes largely in the economy of Bangladesh and gives emphasis only on the philosophy of cutting costs regardless of productivity [6]. Here, noteworthy to mention that since 1985, the growth rate of Bangladesh RMG sector is remarkable because of few privileges and opportunities, such as MFA, Quota and GSP [7] [8]. Meanwhile the apparel sector, all the Bangladeshi garment companies are producing at the low end of the market [9]. Basically they are performing cutting, making and trimming (CMT) activities [2] [10]. Therefore, this industry takes maximum lead time to process an order [11]. According to Rahman and Rahman [12] in Bangladesh the lead time for apparel export varies between 90 - 120 days, whereas the time for Sri-Lanka is about 19 - 45 days, China 40 - 50 days and for India 50 - 70 days for similar products.

Whereas, according to BGMEA [4] Bangladesh Ready-Made Garments (RMG) sector shows remarkable growth and significant contribution in the country's economic development though qualities are yet a crucial problem to discuss. Cost of poor quality of Bangladesh ready-made garments amounted to 18 percent of the operating costs [4]. In this regard, Sharmin Akhter [8] stated that the theory of quality management is new in Bangladesh RMG sector and the state is in a limited understanding condition. In contrast, few organizations that have adopted quality management practices have experienced an overall improvement in corporate performance [7]. However, according to Mamun and Islam [13] in nearly all cases, TQM organizations achieved better employee relations, higher productivity, better customer satisfaction, increased market share and improved profitability. According to Sharmin Akhter [8], little research has been conducted in TQM practices area in Bangladesh Ready-Made Garments sector. According to Heitschold, Reinhardt and Gurtner [14] in today's global competition and economic liberalization, quality has been considered as an important factor for achieving competitive advantage. In case of Bangladesh ready-made garments companies, rather than take the whole process, most local authorities narrowed down their quality approach to few operations in order to cut cost [15]. Practices of TQM are always the most neglected field of research in case of Bangladesh RMG sector as very little research has been conducted in this area [8] [9]. So there is an unsolved and emerging research argument in the field of TQM practices in Bangladesh RMG sector that needs to be answered.

However, many garments companies in Bangladesh don't have full knowledge and 
awareness about the effective implementation of TQM practices whereas they only use and stressed on ISO 9000 which sometimes cause problems [16]. Initially, the certification of ISO 9000 is the initial step of TQM implementation though survey shows that few researchers stressed only on total quality management practices exclusively. Heras et al. [17] also verified the result of these studies. So their study concluded with the view that the application of ISO 9000 concept is primary initiative and TQM is contribute further towards the development and ensure organizational quality performance. As Bangladesh RMG sector is now only used ISO 9000 which need to transformed and transit to TQM implementation. So this research will help to explore this research gap.

On the other hand, according to Seddiqe and Basak [18] Human Resource is the most important asset for Ready-made Garments industry in Bangladesh. Bangladesh RMG sector should focus on proper implementation of HR policies to emphasis quality performance [19]. As each organizations success and quality goal accomplishment is largely depends upon the capabilities of human resources [20]. In this regard according to Ahamed [21] against technological scenery, a thorough analysis of human resource management practices on manufacturing industries especially on Bangladesh RMG sector is very much needed. HRM practices are immensely necessary for the achievement and ensuring quality performance in the organization. It is not secondary rather a crucial and major elements for the implementation of TQM practices [10]. TQM studies related to HR practices can be found in the operations management literature but paid little attention to human resources issues towards gaining sustainable competitive advantage [22]. According to Alsuhaimi [23], indirect effects (mediation) of HRM have been neglected in most empirical research specifically in quality management area. These issues are more significant in Bangladesh RMG sector as never tested the mediating role of HRM practices in the aspect of TQM and sustainable competitive advantage [8]. So there is a huge research gap in this area which needs to justify further.

However, Bangladesh has reached and gains a remarkable development especially in inexpensive workforce context of RMG sector still its development and continuity of growth is not assured [24]. In this respect, according to Fasil and Osada [25] TQM practices are the precondition for the continuous development of business to cope up with the current competitive market and globalization. For identifying the need of TQM practices in Bangladesh RMG sector, it already focused and start working on using quality control issues but unfortunately due to structural difficulties and inflexible hierarchical difficulties quality goals not achieved [8]. So, the defining role of TQM implementation in predicting to gain sustainable competitive advantage in Bangladesh RMG context is required [26]. Hence, the purpose of this study is to generate research idea for investigation the potential link and association of TQM practices in Bangladesh RMG sector to gain sustainable competitive advantage mediated by Human Resource Management practices.

\section{Significance of the Study}

To promote and facilitate TQM adaptation in RMG sector in Bangladesh, this research 
result will contribute significantly. The levels of service offered by ready-made garments companies in Bangladesh were not always acceptable to customers. However, this study is immensely significant for Bangladesh Ready-Made garments companies as for the growing competition, imposition of various new rules and regulations in global business context. The necessity of this research can be justified. One, almost every organization need to develop a quality environment to ensure the quality performance. Two, the purpose of the organizations are mainly to variegate the competitive market as well as boost up the export and revenue through quality performance. Three, to cope up with the changing market condition and ensuring quality performance, organizations need to involve every employee as well as gain commitment. Four, ensuring customer satisfaction is the precondition of business success and sustainability. Five, the importance of group work and an interdisciplinary research was firmly recommended. As well as the findings of this study will be useful to government and other organizations in Bangladesh that are currently implementing TQM practices, as well as those seeking to establish TQM practices within their systems with the aim of improving performance as well as gaining sustainable competitive advantage of their businesses [27]. The current study offers significant values for practitioners since it has considerable managerial significance. At the same time, this research will be significant in Bangladesh garments sector by offering new insights into the various TQM as well as HRM functions. The results of the study will enable buyers as well as customers to buy products from Bangladesh without worrying about the quality standard of products and services. Clearly, theoretical contribution of this study is significant because the research model will form theoretical and practical variables to relate TQM, HRM practices and sustainable competitive advantage. These initiatives will cover the latest research gap on the implementation of TQM, HRM as well as gaining sustainability in the literature. Additionally, it is believed that this study can be replicated in other context such as other product and service industries in Bangladesh. Therefore, this study will assist and explore for future research prosperities and opportunities in TQM area of research. Another relevance of this study is to serve as a guide for researchers who focus on quality management to strategize and help maintain competitive advantage of a given government through implementation of TQM practices [28]. Overall, this research can help to build up remarkable understanding of practicing TQM in Bangladesh RMG sector as well as contribute significantly in building the scientific knowledge in the subject of the research area.

\section{Literature Review}

\subsection{Total Quality Management}

For defining quality there is no unison. Various researchers define the concept of quality in various ways. Quality Gurus defined quality and total quality management in numerous ways, such as, Deming, Crosby, Juran, Garvin, Feigenbaum and Ishikawa etc. every one gave various types of definition. Garvins definition was very remarkable; he defined quality in respect of industry based, usage based, service and product based, 
theoretical based, customer based approaches. Eight attributes of measuring service and product quality is also mentioned by him [29]. According Juran quality is "fitness for use". Planning of quality, control of quality as well as quality improvement is the quality trilogy which was also mentioned by Juran [30]. According to Crosby [31], "quality is the conformance to requirements or specifications and requirements are based on customer needs".

Zero defect quality improvement plans to achieve performance improvement which consist 14 steps also mentioned by Crosby [31]. Deming [32] defined, "quality is a predictable degree of uniformity and dependability, at low cost and suited to the market". To enhance and ensure the performance as well as productivity, Deming also mentioned 14 quality management principles. To improve organizational performance Ishikawa insist on the importance of total quality control. Ishikawa diagram (the fish bone diagram), the cause and effect diagram is also Ishikawa's contribution to identify quality issues and problems [31]. Feigenbaum [33] denoted the ideas and views of organization wise total quality control. And most interestingly he was the initial user of the concept of total quality control in the literatures of quality aspect. According to Feigenbaum [33], "quality is the total composite product and service characteristics of marketing, engineering, manufacturing and maintenance through which the product and service in use will meet the expectations by the customer". The significant elements of these quality development concepts consists commitment of management, strategic quality system approach, measurement of quality, improvement of process, training and development and reducing the various symptoms and reasons of problematic incidents. TQM always give emphasis on customer satisfaction to ensure quality culture by using continuous improvement concept. According to Kanji and Wallace [34], "this culture varies both from one country to another and between different industries, but has certain essential principles which can be implemented to secure greater market share, increased profits, and reduced costs".

TQM should be the set of practices that enable an organization to deliver quality products or services [35]. TQM defined as:

- The way of managing organization to achieve excellence;

- Total-everything;

- Quality-degree of excellence;

- Management-art, act or way of organizing, controlling, planning, directing to achieve certain goals.

According to BS4778:1991, TQM is a management philosophy embracing all activities through which the needs and expectations of the CUSTOMER and COMMUNITY, and the objectives of the organization are satisfied in the most efficient and cost effective manner by maximizing the potential of ALL employees in a continuing drive for improvement."

However, According to Zairi and Youssef [36], "management awareness of the importance of total quality management, alongside business process reengineering and other continuous improvement techniques was stimulated by the benchmarking move- 
ment to seek study, implement and improve on best practices". Originally management commitment and continuous improvement was developed in aspect of using in manufacturing industries though later service sector also included in the usage categories, such as use teller transactions in case of bank's service, processing order in various catalog organizations, etc.). Therefore, to identify various critical factors for TQM, many researches were conducted as well as lots of identified by many researchers as well as academicians and organizations such as "Malcolm Baldrige Award, EFQM (European Foundation for Quality Management), and the Deming Prize Criteria”. On the basis of these researches, a vast majority of managerial concepts, tools, methods, process and strategic system have been developed. For measuring the organizational performance Saraph et al. [37] identified and mentioned 78 items that were categorized in to eight critical factors of TQM. These are: "Role of divisional top management and quality policy, role of the quality department, training, product and service design, supplier quality management, process management, quality data and reporting, and employee relations". Other researchers Flynn et al. [38] suggested other tools to identify major critical factors of TQM. They mentioned seven factors of quality. These are "top management support, quality information, process management, product design, workforce management, supplier involvement, and customer involvement". It's mentionable that Saraph et al. [37] and Flynn et al. [38], their recommended elements are quite identical. Flynn et al. [38] identified the influence of TQM practices in aspect of performance of quality and gaining competitive advantages of the organizations. In this regard, other significant study, Anderson et al. [39] mentioned the basic concepts of TQM practices on the basis of Deming's [32] 14 principles. By using the Delphi technique they could able to reduce the number of elements from 37 to only 7 . The elements are: "visionary leadership, internal and external cooperation, learning, process management, continuous improvement, employee fulfillment, and customer satisfaction". On the basis of the Malcolm Balridge Award measurement tools, Black and Porter [40] suggested critical factors for TQM. Actually they formulated 32 elements which were categorized into 10 different categories of critical factors which are: "corporate quality culture, strategic quality management, quality improvement measurement systems, people and customer management, operational quality planning, external interface management, supplier partnerships, teamwork structures, customer satisfaction orientation, and communication of improvement information".

On the basis of thorough investigation of literatures Ahire et al. [41] also recommended 12 elements to measure critical factors of TQM of firms. The 12 factors are: “supplier quality management, supplier performance, customer focus, statistical process control usage, benchmarking, internal quality information usage, employee involvement, employee training, design quality management, employee empowerment, product quality, and top management commitment". Motwani [42] denoted, "TQM as constructing a house". Firstly, he considers top management commitment as the base line concept. For a better house construction of base line or foundation is essential. After that "employee training and empowerment, quality measurement and benchmarking, 
process management, and customer involvement and satisfaction" should be assured and placed. All these elements are considered as the basic four concepts of constructing a house. When the four concepts or pillars are developed properly then time to give emphasis on product manufacturing and design as well as service quality which are the end step of ensuring TQM practices of organization. In this regard, generally many researchers have been mentioned that the center of effective implementation and execution of TQM practices is top management commitment and capability to work as a visionary leader to cope up with the continuous changing and competitive market [19]. Literatures also showed the necessity of training for the effective implementation of TQM practices [43]. In this respect, Wali, Deshmukh and Gupta [44] also work on selecting TQM elements for organizational success. Though, their research work focused on quality gurus works only. In Bangladesh few researchers [6] [9] [23] work haven been found which was concentrated only on the TQM elements as well as they tried to relate it with Bangladeshi context. In their research they mentioned twelve TQM elements which are responsible for Bangladeshi organizational success [6] [9] [23]. The twelve factors are: Innovation and leadership, employer and employee relationship, rewards and recognition, culture of the organization, Information system, concentration on customer related factor, issues related with ethics, channel of organizational communication, work Team, mutual respect among employees, employee empowerment, continuous improvement.

However, the commonality of concepts of quality and TQM of various researchers are hard to find. Suppose many researchers give emphasis on the "technical and programmatic properties of TQM", whereas another group of researchers pointed out "the general management philosophy". Many other researchers mentioned, "The holistic picture when formulating constructs of TQM" [37]-[42]. Therefore, on the basis of the above literatures, it is easily concluded that the ideas and opinions of various researchers are not identical rather complementary to each other. And in this research more focused will be given on leadership and top management commitment, focus of customer, process approach, training \& development, system approach, continuous improvement, reward and recognition and supplier relationship.

\subsection{Human Resource Management}

Generally, Human resource management (HRM) is the governance of an organization's employees. Absar [45] denoted that due to lack of proper HR policies and procedures, labour-intensive manufacturing firms are facing shortage of workers, and high job turnover in developing countries such as Bangladesh. Shahin and Basak [18] stated that Human Resource is the most important asset for Ready-made Garments industry in Bangladesh for implementing TQM properly. In Bangladesh context very few researchers have been conducted though the importance of HRM practices are immensely important for organizational development, growth and sustainability [21]. In this regard according to Rahman and Rahman [12] there is a rapid growth of industrialization in Bangladesh, yet, the realities for Bangladesh RMG sector is that their people remain 
undervalued, under trained and underutilized. So the potential growth and prospect in Bangladesh RMG sector is huge. And for using this opportunities it should focused on proper implementation of HR policies to emphasis quality performance [19].

Pfeffer [46] introduced $16 \mathrm{HR}$ practices which denote best practice. In context of Bangladesh ready-made garments industry and TQM implementation, in this research we consider the following four practices: recruitment and selection, job analysis, manpower planning, equal employment opportunity act (EEOA).

The main focus of recruitment and selection process is the choosing the right person for the right position. According to Ahamed [47], "workers must be able and willing to cooperate and communicate and accept the way of sharing their knowledge (skills, abilities and experience) based on reciprocity, reputation and altruism". Sharif et al. [48] give emphasized in his study on more general, implicit and less formalized selection criteria are proposed by some authors. In Bangladesh ready-made garments, they don't follow any defined recruitment and selection policies which largely affect employees' turnover and competitiveness [21]. On the other hand, manpower planning is the process-including forecasting, developing and controlling by which a firm ensures that it has-the right number of people, the right kind of people, at the right places, at the right time, doing work for which they are economically most useful. Manpower planning is associated with organizational optimum size of workforce, appropriate training design, compensation system design as well as the future vision of the workforce management which are highly recommended in case of TQM practices in Bangladesh RMG sector [21]. According to Bansari [49], "most garments factories in Bangladesh pay little attention to labour standards and labour rights, disallow trade union activities, unsafe working environment, and ineffective laws and discard fair labour practices, and compliance enforcement is limited and limited role of stakeholders". According to Ahamed, F. [47], "there is a rising fear in Bangladesh that the readymade garments sector may face a decline in demand and social compliance in the RMG industry is a key requirement for most of the world's garments buyers which ensures labour rights, labour standards, fair labour practices and a Code of Conduct".

So for ensuring quality practices and gaining sustainability in RMG sector of Bangladesh much attention should be given to EEO approach to avoid labor unrest and lack of quality performance. Job analysis is required huge impact for starting to implement any HR practices in organization [8]. According to Clark and Kanter [50] for evaluating the organizational performance effectively job analysis also associated with performance management and compensation, recognition and reward. Therefore, according to Dobbins et al. [51], individual skills and competencies are focused in job analysis which is needed for empowering employees which is essentially significant in case of TQM implementation. Lastly, According to Shahin and Basak [18] measuring job fitness is also a part of job analysis process which includes change management, job classification, creativity, and job design and job rotation. In this research, job analysis requires more significant attention in context of Bangladesh ready-made garments industry to gain sustainable competitive advantage for implementing TQM. 
Therefore, according to Absar [45] HRM practices were not given proper acknowledgements and preferences in aspect of Bangladesh RMG sector. So based on literature it is easily understandable that HR practices didn't get much attention which need to be measured and analysis in the aspect of Bangladesh RMG sectors quality performance improvement as in RMG sector human resources is the main advantage for industrial growth and sustainability in business. So this study is required to lift up this expectation to fulfil this research gap.

\subsection{Sustainable Competitive Advantage}

Sustainable competitive advantages are company assets, attributes, or abilities that are difficult to duplicate or exceed and provide a superior or favorable long term position over competitors. According to Bohoris [52] many organizations have already realized that their only way of surviving in today's competitive global market is to become a successful total quality organization. At the same time, Corbett and Rastrick [53] stated that there is significant association between TQM activities and organizational competitiveness. Several other researchers support the findings of this study. All these elements associated with sustainability which could achieve through successful quality implementation. According to Fasil and Osada [25], Total Quality Management is a buzzword for the organizations to safeguard their growth and sustainability in today's strongly competitive and turbulent global scenario.

Currently garments sectors financial performance is satisfactory but to gain the long term sustainability and competitiveness need to focus on TQM practices [12]. According to Zineldin [54], RMG sector needs to retain its customers by providing excellent quality services with minimum or no defects to gain sustainability. So, the defining role of TQM implementation in predicting to gain sustainable competitive advantage in Bangladesh RMG context is required [6]. According to Pinho [55] in the global market, for gaining sustainability practices of TQM received proper attention and acknowledgement. Kanji [56] stated that, "organizations need a framework that is comprehensive, flexible and easy to adopt and help to gain sustainability". According to Talib et al. [57], "the reasons being only to help industries improved its efficiency and competitiveness through quality improvement". TQM practices enhance the whole organizational communication system which is highly required for quality performance in the current business world [58]. Drew and Healy [59] stated that, "TQM allows firms to obtain a high degree of differentiation, satisfying customer needs and strengthening the brand image, and also acts as a tool to reduce costs by preventing mistakes and time wastage, while it allows improvement in the corporation processes". Sila and Ebrahimpour [60] also had given emphasis on conducting research on TQM elements in aspect of various countries as well as various industries. For sustainability, cost reduction as well as product and service differentiation is required and this can be achieved through TQM practices [61].

In this research organizational performance selected as the part of gaining sustainable competitive advantage in Bangladesh RMG sector. According to Li et al. [62] orga- 
nizational performance refers to how well an organization achieves its market-oriented goals as well as its financial goals. In this regard, Stock et al. [63] mentioned that a number of prior studies have measured organizational performance using both financial and market criteria, including return on investment (ROI), market share, profit margin on sales, the growth of ROI, the growth of sales, and the growth of market share. In this research long term performance is focused which is related with organizational long-term sustainability. According to Terziovski [64] TQM is the source of sustainable competitive advantage for business organizations. Teh et al. [65] stated that TQM work as a source of enhancing organizational performance through continuous improvement in organization's activities. At the same time, much research had been conducted to define the relationship among TQM and innovation [66]. The relation between TQM and innovation also need to be considered in aspect of gaining Bangladesh RMG sectors sustainable competitive advantage which is focused in this study.

Therefore, according to Issac et al. [67] TQM has been widely considered as management tool for business stability, growth and prosperity as a tool to keep competitive advantage. In this regard, Dale and Plunkett [68] stated that for last two decades, quality has been considered as one of important factor in manufacturing, service and purchasing to increase sales and profits. There is an inconsistency of research result of these studies and worthy to examine as research gap. According to Lewis et al. [69] the relationship is not so clear when the TQM concept is divided into different dimensions and those dimensions are evaluated for their separate effect. The effect of TQM practices on gaining sustainable competitive advantage in context of Bangladesh ready-made garments industry should be select for further research which will done in this research as there is a huge research gap for it. In this Regard, according to Dean and Bowen [70] the recognition of TQM as a competitive advantage is widespread around the world, especially in Western countries, and today very few companies especially manufacturing companies can afford to ignore the term TQM.

\section{Proposed Model}

Currently RMG's are facing immense global competition [71]. TQM is one of the most widely used operation management practices which most of the developed countries already adopted [2] [72]. Whereas, According to BGMEA [4] the quality of products and services of Bangladesh ready-made garments are a vital issue to concern. RMG can charge high prices as well as increase their profit if they can ensure about their quality operation of product and service delivery [11] [16]. According to Li et al. [63] TQM practices enhance the whole organizational communication system which is highly required for quality performance in the current business world. Recent research proves that Bangladesh RMG sector faces some serious quality issues that have largely influenced the growth rate of this sector [16] [73]. Over the last three decades, there has been a growing interest in Total Quality Management (TQM) as a strategy that is capable of offering organizations a competitive advantage [74].

Many organizations have already realized that their only way of surviving in today's 
competitive global market is to become a successful "total quality organization" [23]. Empirically, In the aspect of Bangladesh garments manufacturing industry a TQM approach unique to the needs and culture of the organization must be developed [2] [9]. At the same time, [19] stated that in the context of TQM, the extent to which HR departments undertake and support organizational sustainability competitive advantage have been examined and seriously questioned. In the current Bangladesh RMG context, HRM researchers paid much attention on TQM practices and implementation in case of organizational profitability [6] [19]. Literatures suggest that, several TQM practices help organization to gain sustainable competitive advantage, specially, developing country like Bangladesh ready-made garments industry [21] [49]. Hence, the following framework is put forward (Figure 1).

Based on the Figure 1, HRM practices will influence or alter the value of link among IV and DV. The IV (Independent Variable) is consists of eight TQM practices such as leadership and top management commitment, customer focus, process approach, system approach, training and development, continuous improvement, supplier relationship, reward and recognition. HRM practices work as mediator which consists four practices. The four functions are: Selection and recruitment, job analysis, manpower planning and equal employment opportunity (EEO) will help to build up the efficient workforce. And lastly, the DV (Dependent Variable) is the sustainable competitive advantage which consists of three criterions to measure, such as organizational performance, innovation and organizational growth in the context of Bangladesh Ready-made Garments industry. DV and IV relation or association will be influenced by the levels of mediator, either strong or weak. In few circumstances, the relation will be either positive or negative depends on the level of mediator. So the impact of mediator will be considerable in aspect of defining the condition of IV and DV.

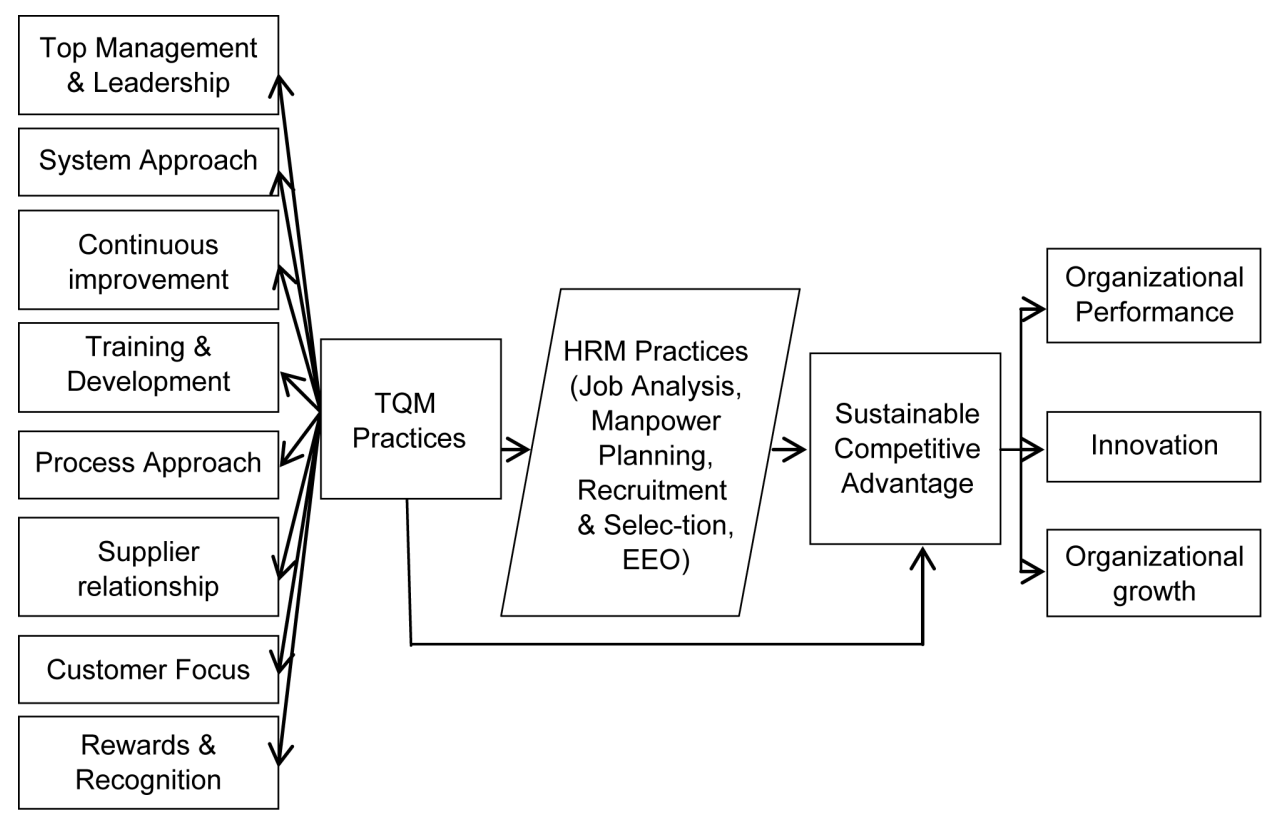

Figure 1. Proposed research model. 


\section{Proposition Testing}

This part explains how the relationship among variables will be managed and how hypotheses developed and tested. Hypothesis tests, or tests for statistical significance, require a number of elements. Before going further, the proper terminologies such as null and alternative, distribution data, critical value, confidence level, two-tailed or one-tailed test and errors should need to be considered. From the purposed framework, null hypothesis can be generated. A null hypothesis is a claim made, a belief expressed, a statistic is held to be the norm. The proposed framework assigned Human Resources Practices as a mediator variable. Based on the literature reviewed in the previous section, therefore these hypotheses are formulated:

H1: Total Quality Management practices are positively associated with Human Resource Management practices.

H2: Total quality management practices are positively associated with sustainable competitive advantage.

H3: Total quality management practices are negatively associated with sustainable competitive advantage.

H4: Human Resources practices are positively associated with sustainable competitive advantage.

A survey methodology will be used to collect data on the variables used in the proposed model. In this research, we tend to use positivism philosophy which is more suitable with the content of this research. The total number of population size is 4296 registered ready-made garments companies which are currently operating in Bangladesh (BGMEA Report 2014-15, source: http://www.bgmea.com.bd). Briefly the research design is shown in the following table (Table 1 ).

The sample of this study will be collected from various RMG companies in Bangladesh in five major cities in Bangladesh, including Dhaka the capital, Narayangonj, Savar, Chittangong and Khulna. Geographical area, size, nature of industry, education of employees and employers, etc. will be considered for selection of appropriate sample. The study tries to ensure absolute representation considering the homogeneity. The gender proportion will equal be considering a targeted sample size of 1000 employees belongs to minimum 500 allied companies in Bangladesh. To arrive at the representative sample size the study will be considered proportionate probability sampling method (PPSS). Structured questionnaire will be used to measure the basic three constructs-

Table 1. Research design.

\begin{tabular}{|c|c|c|c|c|}
\hline \multirow[b]{2}{*}{ Unit of analysis } & \multicolumn{4}{|c|}{ Research design (quantitative) } \\
\hline & Population & Sample size & Sample technique & $\begin{array}{c}\text { Data collection } \\
\text { method }\end{array}$ \\
\hline $\begin{array}{c}\text { Bangladesh } \\
\text { Ready-made } \\
\text { Garments } \\
\text { Companies }\end{array}$ & 4296 & 500 & $\begin{array}{c}\text { Proportionate } \\
\text { Probability } \\
\text { Sampling (PPSS) }\end{array}$ & Questionnaire \\
\hline
\end{tabular}


TQM practices, organizational sustainable competitive advantage, the mediating role of HRM practices. For the purpose of data analysis and hypothesis testing, several statistical tools and methods will be employed using SPSS software and Partial Least Squares-Structural Equation Modeling (PLS-SEM) to measure the mediating effect to the relation.

\section{Conclusion}

Organizations worldwide have been exploring ways to improve business practices to gain competitive edge. The aim of this study was to test the impact of TQM practices on sustainable competitive advantage at ready-made garments companies in Bangladesh. TQM practices have positive and significant effect toward organizational sustainable competitive advantage. The performance and growth rate of Bangladesh RMG sector are diminishing. Current research shows various problems associated with the quality issues. However, the performances of Bangladesh RMG sectors are largely influenced by the international quality standard and regulations. By integrating the HRM practices literature into the TQM and organizational sustainable competitive advantage literature, this study is able to scientifically prove the practitioners of RMG sectors that the introduction of TQM is a compulsory step to gain a sustainable competitive advantage. The question whether this proposed framework or model is valid and reliable is to be answered if further investigation has been carried out. Henceforth, the examinations of each hypothesis and the subsequent empirical investigations of this study are crucial to validate the proposed research framework. It is expected that the study will be beneficial to local manufacturing players, policy makers, government and relevant practitioners.

\section{References}

[1] Siddiqi, H.G.A. (2005) The Ready Made Garment Industry of Bangladesh. 2nd Edition, The University Press Limited, Dhaka.

[2] Rayhan, S.J., Saha, S. and Hassan, M.M. (2014) Factors Affecting the Customer Buying Behavior in Relation to Readymade Garments in Bangladesh. International Research Journal of Marketing, 2, 36-42. https://doi.org/10.12966/irjm.05.03.2014

[3] BKMEA (2014) Export Performance of RMG of Bangladesh for 2011-12 and 2012-13. Annual Report of Bangladesh Knitwear Manufacturers and Export Association.

http://www.bkmea.com/facts-figures.html

[4] Bangladesh Garment Manufacturers and Exporters Association (2015) Annual Report of BGMEA. www.bgmea.com

[5] Seddiqe, I.S. and Basak, A. (2014) Importance of Human Resource Management and the Competitive Advantage: A Case Analysis on Basis of the Textile Industry of Bangladesh. Global Journal of Management and Business Research: A Administration and Management, 14, 93-115.

[6] Akhter, P. (2015) Key Factors of TQM Implementation in the Textile and RMG Industry: A Study of Some Textile and RMG Companies of Bangladesh. IOSR Journal of Business and Management, 17, 26-37.

[7] Rahman, M. (2005) Bangladesh after MFA Phases out. Journal of South Asian, 23, 231-352. 
[8] Akhter, S. (2014) Deming Management Method in the Readymade Garments Industry of Bangladesh. Journal of Management, 9, 178-189.

[9] Rahman, M.M. and Masud, A.K.M. (2011) Quality Improvement in Garments Industry through TQM Approaches. Journal of Management, 12, 111-119.

[10] Apu, A.A. (2012) Compliance in Textile \& Clothing Sector in Bangladesh: Difficulties in Understanding and Implementation. Bangladesh Textile Today. http://www.textiletoday.com.bd/magazine/508

[11] Yunus, M. and Yamagata, T. (2012) The Garment Industry in Bangladesh. In: Fukunishi, T., Ed., Dynamics of the Garment Industry in Low Income Countries: Experience of Asia and Africa, Interim Report, ChousakenKyu, Huokokusho, IDE-JETRO, Chapter 6.

[12] Rahman, K.M.M. andRahman, C.M.L. (2015) Study and Analysis of the Scope of Value Stream Mapping (VSM) Technique Application in a Selected Garments Factory of Bangladesh. International Journal of Engineering Research and General Science, 3, 2091-2730.

[13] Mamun, M. and Islam, M. (2001) Managing Women Work Force: A Case Study of ReadyMade Garments (RMGs) in Bangladesh. The Chittagong University Journal of Commerce, 16, 81-90.

[14] Hietschold, N., Reinhardt, R. and Gurtner, S. (2014) Measuring Critical Success Factors of TQM Implementation Successfully-A Systematic Literature Review. International Journal of Production Research, 52, 6254-6272. https:/doi.org/10.1080/00207543.2014.918288

[15] Uddin, A. (2012) Readymade Garments Industry of Bangladesh: How the Industry Is Affect in Post MFA Period. Unpublished Master's Thesis, Curtin University of Technology, Perth.

[16] Ariful, I.M., Begum, N. and Rashed, C.A.A. (2012) Operational Disturbances and Their Impact on the Manufacturing Business-An Empirical Study in the RMG Sector of Bangladesh. International Journal of Research in Management \& Technology, 2, 233-265.

[17] Heras, I., Dick, G.P.M. and Casadesus, M. (2002) ISO 9000 Registration's Impact on Sales and Profitability: A Longitudinal Analysis of Performance before and after Accreditation. International Journal of Quality \& Reliability Management, 19, 774-791.

http://www.emeraldinsight.com/0265-671X.htm https:/doi.org/10.1108/02656710210429618

[18] Seddiqe, I. and Basak, A. (2014) Importance of Human Resource Management and the Competitive Advantage: A Case Analysis on Basis of the Textile Industry of Bangladesh. Global Journal of Management and Business Research, 14, 93-115.

[19] Absar, N. and Mahmood, M. (2011) New HRM Practices in the Public and Private Sector Industrial Enterprises of Bangladesh: A Comparative Assessment. International Review of Business Research Papers, 7, 118-136.

[20] Huda, S., Akhtar, N. and Akhtar, A. (2011) Employee's View on Job Satisfaction: A Study on Garments Industry in Bangladesh. Indus Journal of Management \& Social Sciences, 5, 1-9.

[21] Ahamed, F. (2013) Could Monitoring and Surveillance Be Useful to Establish Social Compliance in the Ready-Made Garment (RMG) Industry of Bangladesh? International Journal of Management and Business Studies, 3, 88-100.

[22] Mehmood, S., Qadeer, F. and Ahmad, A. (2014) Relationship between TQM Dimensions and Organizational Performance. Journal of Commerce and Social Sciences, 8, 662-679.

[23] Alsuhaimi, M.R. (2012) The Implementation of Total Quality Management in King Saud University. International Journal of Independent Research and Studies, 1, 84-88.

[24] Rahman, A. and Hossain, S. (2010) Compliance Practices in Garment Industries in Dhaka City. Journal of Management, 5, 211-218. 
[25] Fasil, T. and Osada, H. (2011) Multiple Dimensions of TQM Success in Developing Countries: An Empirical Study on Deming Prize Winners from India and Thailand. International Journal of Innovation and Learning, 9, 184-203. https:/doi.org/10.1504/IJIL.2011.038543

[26] Lee, D.H. (2012) Implementation of Quality Programs in Health Care Organizations. Service Business, 6, 387-404. https:/doi.org/10.1007/s11628-012-0141-2

[27] Saha, C. (2012) Global Market Scenario of Textile \& Clothing Trade. http://www.onlineclothingstudy.com/2013/05/globalmarket-scenario-of-textile.html

[28] Khatun, F. (2015) Post Rana Plaza Initiatives and Sustainibility of the RMG Sector. The Daily Star, B1, B3.

[29] Garvin, D.A. (1988) Managing Quality: The Strategic and Competitive Edge. The Free Press, New York.

[30] Juran, J.M. (1995) A History of Managing for Quality: The Evolution, Trends and Future Direction of Managing for Quality. ASQC Quality Press, Milwaukee.

[31] Crosby, P.B. (1996) Quality Is Still Free: Making Quality Certain in uncertain Times. McGraw-Hill, New York.

[32] Deming, W.E. (1982) Quality, Productivity and Competitive Position. MIT Press, Cambridge.

[33] Feigenbaum, A.V. (1991) Quality Control. 3rd Edition, McGraw-Hill, New York.

[34] Kanji, G.K. (1990) Total Quality Management: The Second Industrial Revolution. Total Quality Management, 1, 3-12. https:/doi.org/10.1080/09544129000000001

[35] Rao, A., Carr, L.P., Dambolena I., Kopp, R.J., Martin, J., Rafii, F. and Schlesinger, P.F. (1996) Total Quality Management: A Cross Functional Perspective. John Wiley \& Sons Inc., Hoboken.

[36] Zairi, M. and Youssef, M.A. (1995) Benchmarking Critical Factors for TQM Part I: Theory and Foundations. Benchmarking for Quality Management \& Technology, 2, 5-20. https:/doi.org/10.1108/14635779510081616

[37] Saraph, J.V., Benson, G.P. and Schroeder, R.G. (1989) An Instrument for Measuring the Critical Factors of Quality Management. Decision Sciences, 20, 810-829. https:/doi.org/10.1111/j.1540-5915.1989.tb01421.x

[38] Flynn, B.B., Schroeder, R.G. and Sakakibara, S. (1994) A Framework for Quality Management Research and an Associated Measurement Instrument. Journal of Operations Management, 11, 339-366. https:/doi.org/10.1016/S0272-6963(97)90004-8

[39] Anderson, J.C., Rungtusanatham, M. and Schroeder, R.G. (1994) A Theory of Quality Management Underlying the Deming Management Method. Academy of Management Review, 19, 472-509.

[40] Black, A.S. and Porter, L.J. (1996) Identification of the Critical Factors of TQM. Journal of Decision Sciences, 27, 1-21. https:/doi.org/10.1111/j.1540-5915.1996.tb00841.x

[41] Ahire, S.L. and Golhar, D.Y. (1996) Quality Management in Large Versus Small Firms. Journal of Small Business Management, 34, 1-13.

[42] Motwani, J. (2001) Measuring Critical Factor of TQM. Measuring Business Excellence, 5, 27-30. https:/doi.org/10.1108/13683040110397284

[43] Quazi, H.A., Hong, E.W. and Meng, E.T. (2002) Impact of ISO 9000 Certification on Total Quality Management Practices: A Comparative Study. Journal of Total Quality Management, 13, 53-67. https:/doi.org/10.1080/09544120120098564

[44] Wali, A., Deshmukh, G.S. and Gupta, D.A. (2003) Critical Success Factors of TQM. Journal of Production Planning \& Control, 14, 3-14. https:/doi.org/10.1080/0953728021000034781 
[45] Absar, S.S. (2001) Problems Surrounding Wages: The Ready-Made Garments Sector in Bangladesh. Journal of Labor and Management in Development, 2, 123-136.

[46] Pfeffer J. (1998) The Human Equation: Building Profits by Putting People First. Harvard Business School Press, Boston.

[47] Ahamed, F. (2012) Improving Social Compliance in Bangladesh's Ready-Made Garment Industry. Journal of Labour and Management in Development, 13, 1-26. http://www.nla.gov.au/openpublish/index.php/lmd/article/viewFile/2269/3148

[48] Ahmed, S., Mahbubor Rahman, S., Islam, M. and Habib, A. (2014) Effect of Total Quality Management (TQM) on Employee Satisfaction in the Apparel Industries of Dhaka Division. European Scientific Journal, 22, 251-269.

[49] Bansari, N. (2010) Textile and Clothing Sector in Post MFA Regime: A Case from Bangladesh, Gender and Trade. Commonwealth Secretariat. http://www.genderandtrade.org

[50] Clark, C. and Kanter, S. (2011) Violence in the Readymade Garments (RMG) Industry in Bangladesh. Center for International and Comparative Studies, Vol. 3, 6-12.

[51] Dobbins, G.H., Cardy, R.L. and Carson, K.P. (1991) Examining Fundamental Assumptions: A Contrast of Person and System Approaches to Human Resource Management. In: Ferris, G.R., Ed., Research in Personnel and Human Resources Management, JAI Press, Greenwich, Vol. 9, 1-38.

[52] Bohoris, G.A. (1995) A Comparative Assessment of Some Major Quality Awards. International Journal of Quality and Reliability Management, 12, 30-43. https:/doi.org/10.1108/02656719510101178

[53] Corbett, L.M. and Rastrick, K.N. (2000) Quality Performance and Organizational Culture: A New Zealand Study. International Journal of Quality \& Reliability Management 17, 14 26. https:/doi.org/10.1108/02656710010300126

[54] Zineldin, M. (2006b) The Royalty of Loyalty: CRM, Quality and Retention. Journal of Consumer Marketing, 23, 430-437. https:/doi.org/10.1108/07363760610712975

[55] Pinho, J.C. (2008) TQM and Performance in Small Medium Enterprises: The Mediating Effect of Customer Orientation and Innovation. International Journal of Quality \& Reliability Management, 25, 256-275. https:/doi.org/10.1108/02656710810854278

[56] Kanji, G.K. (2001) Forces of Excellence in Kanji’s Business Excellence Model. Total Quality Management, 12, 259-272. https:/doi.org/10.1080/09544120120025311

[57] Talib, F., Rahman, Z. and Qureshi, M.N. (2010) The Relationship between Total Quality Management and Quality Performance in the Service Industry: A Theoretical Model. International Journal of Business Management and Social Sciences, 1, 113-128.

[58] Lee, S.M., Rho, B.-H. and Lee, S.-G. (2003) Impact of Malcolm Baldrige National Quality Award Criteria on Organizational Quality Performance. International Journal of Production Research, 41, 2003-2020. https:/doi.org/10.1080/0020754031000077329

[59] Drew, E. and Healy, C. (2006) Quality Management Approaches in Irish Organizations. The TQM Magazine, 18, 358-371. https:/doi.org/10.1108/09544780610671039

[60] Sila, I. and Ebrahimpour, M. (2003) Examination and Comparison of the Critical Factors of Total Quality Management (TQM) across Countries. International Journal of Production Research, 41, 235-268. https:/doi.org/10.1080/0020754021000022212

[61] Sharma, M. and Kodali, R. (2008) TQM Implementation Elements for Manufacturing Excellence. The TQM Magazine, 20, 599-621. https:/doi.org/10.1108/17542730810909365

[62] Li, J.H., Andersen, A.R. and Harrison, R.T. (2003) Total Quality Management Principles and Practices in China. International Journal of Quality \& Reliability Management, 20, 
1026-1050. https:/doi.org/10.1108/02656710310500833

[63] Stock, G.N., McFadden, K.L. and Gowen, C.R. (2007) Organizational Culture, Critical Success Factors, and the Reduction of Hospital Errors. International Journal of Productions Economics, 106, 368-392. https:/doi.org/10.1016/j.ijpe.2006.07.005

[64] Terziovski, M. (2006) Quality Management Practices and Their Relationship with Customer Satisfaction and Productivity Improvement. Management Research News, 29, 414-424. https:/doi.org/10.1108/01409170610690871

[65] Teh, P.-L., Yong, C.-C., Arumugam, V. and Ooi, K.-B. (2009) Does Total Quality Management Reduce Employees' Role Conflict? Industrial Management and Data Systems, 109, 1118-1136. https:/doi.org/10.1108/02635570910991337

[66] Prajogo, D.I. and Sohal, A.S. (2006) The Integration of TQM and Technology /R\&D Management in Determining Quality and Innovation Performance. The International Journal of Management Science, 34, 296-312.

[67] Issac, G., Rajendran, C. and Anantharaman, R.N. (2004) A Holistic Framework for TQM in the Software Industry: A Confirmatory Factor Analysis Approach. The Quality Management Journal, 11, 35-60.

[68] Dale, B.G. and Plunkett, J.J. (1995) Quality Costing. 2nd Edition, Chapman and Hall, London.

[69] Lewis W.G., Pun, K.F. and Lalla, T.R.M. (2006) Empirical Investigation of the Hard and Soft Criteria of TQM in ISO 9001 Certified Small and Medium Sized Enterprises. International Journal of Quality \& Reliability Management, 23, 964-985. https:/doi.org/10.1108/02656710610688167

[70] Dean, J.W. and Bowen, D.E. (1994) Management Theory and Total Quality: Improving Research and Practice through Theory Development. Academy of Management Review, 19, 392-418.

[71] Heras, I. Marimon, F. and Casadesus, M. (2009) Impact on Competitiveness of the Tools for Quality Management. Journal of Economics and Business, 41, 7-35.

[72] Jung, J. and Wang, Y. (2006) Relationship between Total Quality Management (TQM) and Continuous Improvement of International Project Management (CIIPM). Technovation, 26, 716-722. https:/doi.org/10.1016/j.technovation.2006.01.003

[73] Haque, A., Sarwar, A.A.M., Yasmin, F., Anwar, A. and Nuruzzaman. (2012) The Impact of Customer Perceived Service Quality on Customer Satisfaction for Private Health Centre in Malaysia: A Structural Equation Modeling Approach. Information Management and Business Review, 4, 257-267.

[74] Jahid, H. (2013) The Competitiveness of Ready Made Garments Industry of Bangladesh in Post MFA Era: How Does the Industry Behave to Face the Competitive Challenge. British Journal of Economics, Management \& Trade, 3, 296-306. https:/doi.org/10.9734/BJEMT/2013/4321 
Submit or recommend next manuscript to SCIRP and we will provide best service for you:

Accepting pre-submission inquiries through Email, Facebook, LinkedIn, Twitter, etc. A wide selection of journals (inclusive of 9 subjects, more than 200 journals)

Providing 24-hour high-quality service

User-friendly online submission system

Fair and swift peer-review system

Efficient typesetting and proofreading procedure

Display of the result of downloads and visits, as well as the number of cited articles

Maximum dissemination of your research work

Submit your manuscript at: http://papersubmission.scirp.org/

Or contact ajibm@scirp.org 